\section{Ohio's polymer industry adds jobs, strengthens economy}

\section{www.polymerohio.org}

D espite the economic downturn in the United States, the advanced materials and polymer industry in the state of Ohio is boasting new jobs, new companies, and new opportunities for existing companies. This success is largely the result of an ongoing economic development program within the state, and a strong support network within its polymer research and industry community.

Since 2002, Ohio has invested more than $\$ 1.6$ billion in Ohio Third Frontier, a bond-funded development program designed to create new technology-based products, companies, industries, and jobs within the state. The original program was for 10 years, but in May 2011, voters approved a $\$ 700$ million extension through 2015. Ohio Third Frontier supports programs in seven areas: advanced materials, fuel cells, photovoltaics, advanced energy, biomedical, medical imaging, and sensors.

To date the advanced materials program has received over $\$ 200$ million from Ohio Third Frontier, with additional funds supporting materials research, development, and manufacturing in the advanced energy program and others. This money has been leveraged with private investments and federal grants to create an even bigger impact.

Ohio Third Frontier is more than a grant distribution program according to Norm Chagnon, its executive director. The Third Frontier aims to create a culture of collaboration among Ohio businesses and research institutions that lasts beyond the funding, and to build an Ohio that embraces innovation and entrepreneurship.

The advanced polymers group at the University of Dayton Research Institute (UDRI) tailors polymers specifically to meet the needs of customers such as the Department of Defense. The group has been involved in multiple projects funded by the Third Frontier. One of the main benefits has been increased collaboration between Ohio universities, said Alex Morgan, a senior research scientist and group leader for advanced polymers at UDRI. "Ohio has a pretty strong research university culture and research university capability," he said. "Now universities are a lot more inclined to collaborate and work together than in the past."

Another benefit has been growing business opportunities for UDRI. "Ohio Third Frontier helped us branch out and bring in more industry business," said Morgan, because local companies are more aware of UDRI's capabilities and specialties. Other laboratories and companies have also experienced growth as a result of local networking opportunities and partnerships through Ohio Third Frontier.

Chagnon cited the increased collaboration among universities, businesses, and research institutions as a source of pride for the state. "Hopefully we are creating sustainable clusters of economic activity within the state that won't have to rely on ongoing investments from the state," he said.

In 2001, shortly before the Ohio Third Frontier began, a group of senior leaders from industry, academia, and government formed two organizations to lead and support the polymer community - the Ohio Polymer Strategy Council (OPSC) to provide strategic direction and PolymerOhio to serve and connect the community. PolymerOhio is one of seven Ohio Edison Technology Centers, statewide organizations that provide services to technology-based businesses.

A key component to the success of

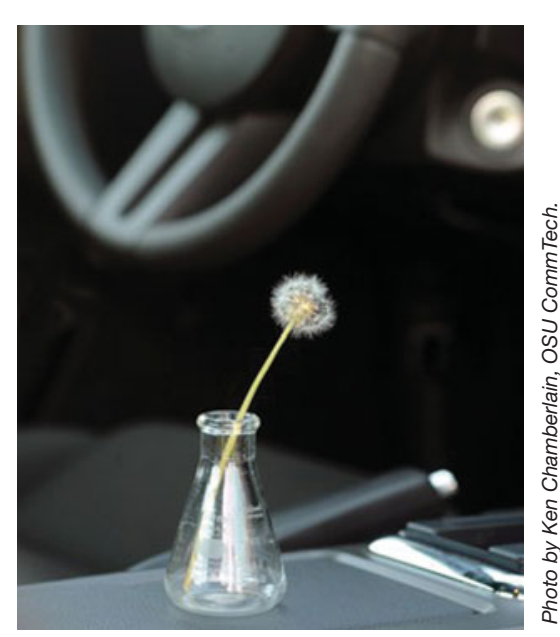

The Ohio State University's Ohio BioProducts Innovation Center (OBIC) was established in 2005 with the help of an \$11.5 million Third Frontier Award. OBIC was instrumental in starting a national consortium to develop Ohiogrown Russian dandelions as an alternative source of rubber for automobiles and other industrial applications.

the Ohio polymer industry has been the strategic direction provided by OPSC. In 2004, the group released a road map highlighting potential growth areas, business opportunities, and important technologies. In early 2011, the group released an updated road map recognizing the industry successes, but also urging the community to stay focused on innovation and bringing products to market quickly in order to maintain their competitive edge.

From research and development to manufacturing and production, Ohio is home to companies along the entire supply chain. One of PolymerOhio's main functions is networking - to connect those with technical or business needs with local expertise. According to CEO Wayne Earley, when a company calls PolymerOhio seeking assistance, the organization can often find contacts willing to help within hours.

More than $80 \%$ of Ohio's polymer establishments have fewer than $100 \mathrm{em}$ ployees. Recognizing the importance of small businesses and start-up companies, PolymerOhio maintains a set of computational and simulation tools that small and medium-sized companies can use on an affordable, pay-per-use basis. Members can also participate in shared pur- 
chasing and services programs to reduce their operational costs.

With the Ohio Third Frontier, OPSC, PolymerOhio, and investments in other organizations such as the Ohio Bioproducts Innovation Center, Ohio Nano-Network, the National Composite Center, and the Center for Multifunctional Polymers, Nano-Materials and Devices, the state of Ohio is a growing hub of polymer activity. Companies and research institutions are engaged at all points along the supply chain in areas ranging from aerospace to flexible displays.

The polymer industry in Ohio employs approximately 130,000 people at 2440 establishments. It has generated nearly $\$ 50$ billion in economic activity and more than $\$ 1.3$ billion in exports annually in recent years. For more information on Ohio's investments in the polymer community, visit www. PolymerOhio.org.

\section{Kendra Redmond}

Science Europe to strengthen collaboration among national research organizations
L ast fall, Europe's national research organizations announced the founding of Science Europe, an organization that brings together 50 organizations from across Europe. Based in Brussels, Science Europe will promote the collective interests of its member organizations, and streamline the coordination of policies and activities. Its creation will accelerate progress on implementing the actions set out in the road map for the realization of the European Research Area developed by the European Heads of Research Councils (EUROHORCs) and the European Science Foundation in 2009. Its location in Brussels will enable Science Europe to work in effective partnership with the European Commission and other European organizations with similar aims.

In addition to coordinating policy work among its members, in 2012, Science Europe will establish six scientific committees that will be made up of leading European researchers to ensure a direct voice for the scientific community in the organization's strategic outlook, policies, and priorities.

As Science Europe's first president, Assembly-elected Paul Boyle of the
Research Councils UK said, "Science Europe will provide a strong single voice for research funding and performing organizations in Europe; it is essential for us to work together to support research to address the global challenges we face today."

Preparations for the establishment of Science Europe have been in development for two years, and a Pilot Board, with a small Pilot Office in Brussels, has been operating since February 2011 to prepare for its establishment and enable a Secretariat to be operational quickly. The Pilot Office has also been working closely with the European Science Foundation to ensure coherence and avoid duplication of activity.
German Research Foundation to fund three DNP-NMR devices for materials science

W

ith support from the Deutsche Forschungsgemeinschaft (DFG, German Research Foundation) three German universities are to obtain innovative dynamic nuclear polarization-nuclear magnetic resonance (DNP-NMR) equipment for use in materials science and the life sciences. As part of an ongoing major instrumentation initiative, a sum of almost $€ 5$ million is available to provide this technology at the Universities of Darmstadt, Düsseldorf, and Frankfurt.

The key feature of DNP-NMR tech- nology is the combination of solidstate NMR spectroscopy with intensive high-frequency irradiation of the samples during the measurement. This technique increases the sensitivity of the NMR measurement by approximately two orders of magnitude and so allows completely new categories of samples to be investigated, according to the DFG. In contrast to other approaches to more sensitive NMR measurements, the new method now being funded enables continuous DNP amplification for the first time, and thereby affords wider appli- cation in a range of different scientific fields, said the DFG. This means that the DNP-NMR technique may facilitate a better understanding of the interactions taking place on the molecular level.

In materials science, for example, this instrumentation can be used for studying composite materials, glasses, or inhomogeneous polymers.

The equipment to be funded by the DFG is intended to contribute to exploiting and evaluating the potential of the DNP-NMR technology. At all funded sites, measurement time will be available for external users, for which they will be expected to pay a share of the running costs. 